\title{
Improved Integrated Thematic Learning Process with Model Discovery Learning in Elementary School
}

\author{
Vina Iasha ${ }^{1)}$, Reza Rachmadtullah ${ }^{2)}$, Rasmitadila $^{3)}$ \\ \{vina.iasha@gmail.com ${ }^{1)}$; reza@unipasby.ac.id ${ }^{2}$; rasmitadila@unida.ac.id ${ }^{3}$ \}
}

Department of Elementary School Teacher Education, Universitas Negeri Jakarta. Indonesia ${ }^{1)}$

Department of Elementary School Teacher Education, University PGRI Adi

Buana, Surabaya. Indonesia ${ }^{2)}$

Department of Elementary School Teacher Education, Universitas Djuanda,

Bogor, Jawa Barat, Indonesia ${ }^{3}$

\begin{abstract}
This study aims to describe the improvement of the integrated thematic learning process using the Discovery Learning model in elementary school. This study uses a qualitative and quantitative approach with the type of research is classroom action research. The subjects of this study were teachers and 37 fourth grade students of 04 Birugo State Elementary School, Bukittinggi City. The results of the study have increased, the observation of the Learning Implementation Plan (RPP) in the first cycle is $79.15 \%$ and the second cycle is $94.4 \%$. The teacher aspect of cycle I was $77.65 \%$ to $91.6 \%$ in cycle II and in the aspect of students in the first cycle $79.15 \%$, cycle II 88.9. Assessment of students in the first cycle, namely 71.12 increased in the second cycle, namely 81.82. So, the Discovery Learning model can improve integrated thematic learning processes.
\end{abstract}

Keywords: Thematic Learning, Model Discovery Learning, Elementary School

\section{Introduction}

Integrated thematic learning is integrated learning that uses themes to link multiple subjects so that they can provide meaningful experiences to students [1], [2]. The characteristics of integrated thematic learning are student-centered, provide direct experience to students, inter-subject separation is not visible, present the concepts of various subjects in a learning process, are flexible, and learning outcomes can develop in accordance with student interests and needs [3]-[5]. Discovery learning model is suitable for use in integrated thematic learning in order to improve student learning processes because this model students are encouraged to find their own knowledge, through data collection, data processing, and drawing conclusions so that learning will be interesting and fun for students and the output produced by students will last a long time for students to remember [6], [7]. According to Hosnan (2014: 282) "Discovery Learning is a model for developing active ways of learning students by finding themselves, investigating themselves, then the results obtained will be faithful and durable in memory, students will not easily forget."[8] Discovery Learning is a series of learning activities that involve maximally all the ability of students to search and 
investigate systematically, critically, and logically so that they can find their own knowledge, attitudes and skills as a form of existence changes in behaviour [6], [9]. Based on the description above, the purpose of this study is to describe the improvement of integrated thematic learning process by using discovery learning models in class IV 04 Birugo State Elementary School, Bukittinggi City.

\section{Method}

This study uses a type of classroom action research using qualitative and quantitative data analysis with teacher research subjects and 37 fourth grade students of State Elementary School 04 Birugo, Bukittinggi City (primary data of 04 Birugo State Elementary School, Bukittinggi City, 2016). This study uses a research flow model of Kemmis \& Mc Taggart [10],: "Broadly speaking there are four stages that are passed, namely (1) planning, (2) implementation, (3) observation, and (4) reflection. Research data in the form of observations, interviews, and tests of integrated thematic learning with discovery learning models in fourthgrade students of 04 Birugo State Elementary School, Bukittinggi City. The data is about matters relating to planning, implementation, and assessment of learning in the form of information on the implementation of learning related to teacher and student behavior which includes the interaction of learning between teacher-students, students, and student-teachers in integrated thematic learning and The research instrument was collected based on observations of the implementation plan of learning, the implementation of learning actions from the activities of the teacher and students, and the assessment test of the process and learning outcomes. Data were collected for 3 days in two weeks, namely May 2, May 10, and May 12, 2016 by means of the researcher being a practitioner teacher in the integrated thematic learning process by using discovery learning models in class IV 04 Birugo State Elementary School, Bukittinggi City.

\section{Results and Discussion}

\subsection{Results}

The results of the assessment of integrated thematic learning by using discovery learning models in fourth grade students of 04 Birugo State Elementary School in Bukittinggi City. For more details, see the graph below:

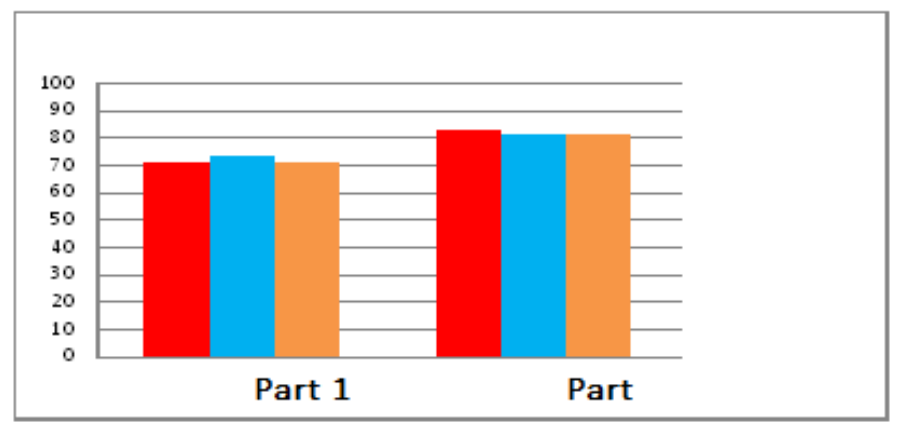

Fig. 1. Improved Thematic Learning Assessment Results Integrated against students per cycle 
The results obtained are based on the results of observations on the implementation plan of learning cycle I 79.15\% (Good). Based on the results of observations carried out on teacher activity cycle I $77.65 \%$ (Good) while the aspect of students in the first cycle was $79.15 \%$ (Good). Assessment of students by using the discovery learning model seen during the learning process that takes place. Based on the assessment of the process and student learning outcomes from aspects of attitudes, knowledge, and skills obtained an overview of aspects of attitude, the success of students from the attitude aspect seen during the learning process takes place during the first cycle is 70.73 with a conversion value of 2.65 (Good), aspects of knowledge 72,57 with a conversion of 2.71 (Good), the skill aspect gained an average of 70.84 with a conversion of 2.64 (Good). Thus the value recapitulation of the three aspects is 71.12 with a conversion of 2.66 (B-) with $75.6 \%$ student completeness.

Based on the results of observations on the implementation plan of learning, cycle II learning obtained a score of 34 from a maximum score of 36 with a percentage of $94.4 \%$ (AB). Based on the results of observations made on teacher activities, in cycle II learning the total scores obtained were 33 from a maximum score of 36 with a percentage of $91.6 \%$ (AB). While the aspect of students, the score obtained 32 from a maximum score of 36 with a percentage of $88.9 \%$ (AB). Assessment of students by using the discovery learning model seen during the learning process that takes place. Based on the assessment of the process and student learning outcomes from the aspects of attitudes, knowledge, and skills obtained the description that of the 37 students all students are able to achieve a minimum standard of learning completeness. From the learning process and results obtained can be described: (1) aspects of attitude, the success of students from the attitude aspect seen during the learning process takes place during cycle II is 82.97 with a conversion of 3.43 (Good); (2) Aspects of knowledge, the success of students from the aspect of knowledge at this meeting is 81.64 with a conversion of $3.28(\mathrm{~B}+)$; (3) Aspects of skill, the success of students from the aspect of skills at this meeting is 81.01 with a conversion of $3.22(\mathrm{~B}+)$. Thus the recapitulation of values from these three aspects is 81.82 with a conversion value of $3.33(\mathrm{~B}+)$.

\subsection{Discussion}

The implementation of integrated thematic learning is carried out in accordance with the established plan. In the implementation of learning, researchers refer to the planning contained in the form of learning implementation plans. As stated by Majid [11] said that "the implementation plan of learning is a plan that describes the procedures and organization of learning to achieve a basic competence specified in the standard of content and has been described in the syllabus."

\section{Conclusion}

Assessment of students in improving the integrated thematic learning process by using discovery learning models in cycle I obtained the percentage of the average value, which is 71.12 with a conversion of 2.66 (B-) with a percentage of students completeness $75.6 \%$, in cycle II increased to 81.82 with a conversion of $3.33(\mathrm{~B}+)$ percentage of student completeness $100 \%$. Thus, discovery learning models can improve integrated thematic learning processes. 


\section{Reference}

[1] F. Kurniasari., "Implementasi Pendekatan Saintifik pada Penugasan Aktivitas di Buku Teks Bahasa Indonesia Kelas VII SMP Berdasarkan Kurikulum 2013," J. Pendidik. Edutama, vol. 2, no. 1, pp. 9-26, 2015.

[2] R. Rachmadtullah and D. Kusmaharti, "Education as the Culture Process," Int. J. Multidiscip. Approach Stud., vol. 5, no. 3, pp. 131-135, 2018.

[3] R. A. Sani, Pembelajaran Saintifik untuk Implementasi Kurikulum 2013. Jakarta: Bumi Aksara, 2014.

[4] M. S. Sumantri, A. W. Prayuningtyas, R. Rachmadtullah, and I. Magdalena, "The Roles of Teacher-Training Programs and Student Teachers' Self-Regulation in Developing Competence in Teaching Science," Adv. Sci. Lett., vol. 24, no. 10, pp. 7077-7081, Oct. 2018.

[5] M. S. Sumantri and R. Rachmadtullah, "The effect of learning media and self regulation to elementary students' history learning outcome," Adv. Sci. Lett., vol. 22, no. 12, pp. 4104-4108, 2016.

[6] A. In'am and S. Hajar, "Learning Geometry through Discovery Learning Using a Scientific Approach,” Int. J. Instr., vol. 10, no. 01, pp. 55-70, Jan. 2017.

[7] M. Sumantri and N. Syaodih, Perkembangan Peserta Didik. Jakarta: Universitas Terbuka, 2006.

[8] M. Hosnan, The Scientific and Contextual Approach In 21st Century Learning (The key to successful implementation of the 2013 curriculum). Bogor: Ghalia Indonesia, 2014.

[9] M. S. Sumantri, Strategi Pembelajaran Teori dan Praktik Ditingkat Pendidikan Dasar. Jakarta: Rajawali Pres, 2015.

[10] S. Kemmis and R. McTaggart, Participatory action research: Communicative action and the public sphere. Sage Publications Ltd., 2005.

[11] A. Majid, Perencanaan pembelajaran. Bandung: PT Remaja Rosdakarya. Bandung: PT Remaja Rosdakarya., 2008. 